\title{
JURNAL SOLUSI
}

\section{Editor in Chief:}

Junaidi Affan (STIE SBI Yogyakarta)

\section{Managing Editor:}

Surawan Setyabudi S (STIE SBI Yogyakarta)

\section{Editor Board:}

Frasto Biyanto (STIE YKPN Yogyakarta)

Sukhemi (Universitas PGRI Yogyakarta)

Hari Kusuma Satria Negara (UPN Yogyakarta)

Yusti Pujisari (STIE SBI Yogyakarta)

Hardoko (STIE SBI Yogyakarta)

Ilham Tri Murdo (STIE SBI Yogyakarta)

\section{Layout Editor:}

Triyan Agung Laksono (STIE SBI Yogyakarta)

\section{Reviewer/Peninjau:}

Zainal Mustafa (Universitas Islam Indonesia)

Dwipraptono Agus Harjito (Universitas Islam Indonesia)

Kadari (STIE YKP Yogyakarta)

Saifudin Zuhri (STIE SBI Yogyakarta)

Lucia Ika Fitriastuti (STIE SBI Yogyakarta)

Enita Binawati (STIE SBI Yogyakarta)

\section{Alamat Sekretariat:}

STIE SBI Yogyakarta

Jl.Ring Road Utara No.17 CondongCatur Yogyakarta

Phone 0274-887984

Email: lppmstiesbi@gmail.com

\section{Distribusi dan Sirkulasi}

Bag. Perpustakaan STIE SBI Yogyakarta 


\section{Jurnal Solusi}

Volume I5, Nomor 2, Desember 2020

ISSN 1907-2376

\section{DAFTAR ISI}

Ilham Tri Murdo, Dampak Covid-19 Terhadap Perekonomian Indonesia Junaidi Affan Dari Sisi Pendapatan Nasional Pendekatan Pengeluaran $\sim 111$

Rini Susilawati

Pengaruh Konsep Pelayanan Terhadap Keputusan Pembelian dan Tingkat Pendapatan Pada Masa Sebelum, Awal dan New Normal Pandemi (Studi Komparasi Pada Café-Café di Minggir Yogyakarta) 135

Ch. Dini Ika Handayani

Kuswadi Rustam

Yunita Fitri

Wahyuningtyas,

Nur Fitriyani

Dila Damayanti, Maharani

Nurul Muti'ah, Dian Retnaningdiah
Efektifitas Pembelajaran Melalui Media Daring Ditinjau Dari Hasil Belajar Mahasiswa Pada Masa Pandemi Covid 19 155

Analisis Kepuasan Masyarakat Terhadap Pelayanan 27 Puskesmas di Kabupaten Mojokerto Berdasarkan Indeks Kepuasan Masyarakat $\sim 169$

Pengaruh Kualitas Produk, Harga dan Keragaman Produk Terhadap Keputusan Pembelian di Maneko Digital 191

Analisis Kualitas Layanan Jasa Transportasi Online (Studi Pada Pengguna Gojek di Daerah Istimewa Yogyakarta) $\sim 207$

Pengaruh Pembiayaan Mikro Syariah dan Pengetahuan Penyusunan Laporan Keuangan Terhadap Perkembangan UMKM (Studi Kasus Anggota BWM Usaha Mandiri Sakinah Yogyakarta) 223 


\title{
Analisis Kepuasan Masyarakat Terhadap Pelayanan 27 Puskesmas di Kabupaten Mojokerto Berdasarkan Indeks Kepuasan Masyarakat
}

\author{
Kuswadi Rustam \\ Program Studi Administrasi Bisnis Politeknik Sawunggalih Aji Purworejo \\ email: kuswadi_sleman@yahoo.com
}

\begin{abstract}
The Measurement of community satisfaction in the healthy sector is an important element in the evaluation of the performance of the Govermnent in Mojokerto Regency. In this case, the Public Health Centre (PHC) should become a public institution based on community-based services which is the best, efficient, and more effective. For this reason, research on the level of satisfaction of PHC in Mojokerto is aimed to determine the correlation among satisfaction index and the community expectations in a PHC services in Mojokerto Regency. The method was used is a qualitative descriptive, the research is designed to combines qualitative and quantitative data. The object of the research is the people who use the PHC in 27 sub-districts in Mojokerto district. The sampling technique used in this study was purposive accidental sampling at the research location with 150 respondents per PHC location. Respondent data collection was carried out by interview and questionnaire techniques. the obtained data then calculated the weighted average value, community satisfaction index (IKM) and conversion in the form of a table of perception and IKM values. The results of the analysis show that the highest average conversion value of each service element of the 27 PHC is the conversion value of the cost / tariff element (U4) of 89.01 or reaches the service quality value is $A$. While the lowest average conversion value is the service element of complaint handling. (U4) 84.40, is in the value of service quality is B, while the other 20 of other PHC status is Good IKM.
\end{abstract}

Kata Kunci: Community Satisfaction, Service, Satisfaction Index

\begin{abstract}
Abstrak
Pengukuran kepuasan masyarakat di sektor kesehatan menjadi elemen penting dalam evaluasi kinerja Pemerintah Kabupaten Mojokerto dalam hal ini puskesmas dituntut untuk menjadi institusi public dengan pelayanan berbasis masyarakat yang lebih baik, efisien, dan efektif. Untuk itu, penelitian mengenai tingkat kepuasan pelayanan puskesmas di Mojokerto perlu dilakukan guna mengetahui sejauh mana pelayanan Puskesmas di Kabupaten Mojokerto mampu memenuhi harapan masyarakat. Metode penelitian ini menggunakan desain penelitian deskriptif kualitatif yang memadukan antara kualitatif dan kuantitatif. Obyek peneltian adalah masyarakat yang memanfaatkan puskesmas di 27 kecamatan di kabupaten Mojokerto. Teknik sampling yang
\end{abstract}


digunakan dalam penelitian ini adalah purposive accidental sampling di lokasi penelitian dengan jumlah responden per lokasi puskesmas sebanyak 150 orang, pengambilan data responden dilakukan dengan teknik wawancara dan kuisioner. Data hasil responden kemudian di hitung nilai rata-rata bobot tertimbang, indeks kepuasan masyarakat (IKM) dan konversi dalam bentuk tabel nilai presepsi dan IKM. Hasil analisis menunjukkan bahwa nilai konversi rata-rata tiap unsur pelayanan dari 27 puskesmas tertinggi adalah nilai konversi pada unsur biaya / tarif (U4) sebesar 89,01 atau mencapai nilai kualitas pelayanan A. Sedangkan nilai konversi rata-rata terendah adalah unsur pelayanan penanganan pengaduan (U4) 84,40, berada pada nilai kualitas pelayanan B, sedangkan 20 puskesmas lainnya mencapai IKM Baik.

\section{Kata Kunci: Kepuasan Masyarakat, Pelayanan, Indeks Kepuasan}

\section{PENDAHULUAN}

Reformasi Birokrasi adalah sebuah program yang disuarakan masyarakat sebagai sebuah keinginan dari masyarakat yang menuntut adanya perubahanan pradigma birokrasi Indonesia menjadi birokrasi yang lebih bersih dan melayani. Perubahan pradigma ini merupakan tuntutanyangwajar jika kita pahami filosofi birokrasi itu sendiri, karena definisi birokrasi menurut Harta dan Bambang (2017:2) adalah sebuah sistem dalam organisasi besar yang mengatur mekanisme pelayanan terhadap masyarakat dilaksanakan oleh para birokrat yang sebagian besar adalah aparatur negara. Oleh karena itu, reformasi birokrasi yang dilakukan oleh pemerintah lebih ditekankan pada pada fungsi pelayanan yang maksimal.

Pemerintah melalui UU No. 22 Tahun 1999 yang disempurnakan dengan UU No. 32 Tahun 2004 tentang pemerintahan daerah bertujuan untuk lebih mendekatkan dan meningkatkan pelayanan publik kepada masyarakat lokal serta mengupayakan terciptanya pemerataan pembangunan (Kamarni, 2011:2). Pemerintah daerah sebagai service provider dan service arranger memiliki kewenangan yang luas untuk memenuhi berbagai kebutuhan masyarakat setempat. Keberhasilan pemerintah daerah dalam menjalankan pelayanan publik ditentukan oleh faktor-faktor berikut: responsif, informatif, accessible, koordinatif, Efisien, dan akomodatif terhadap saran atau keluhan pengguna (Maryam, 2016:13). Salah satu upaya untuk meningkatkan kualitas pelayanan publik tersebut adalah dengan melakukan evaluasi untuk menilai kinerja pelayanan yang disediakan oleh berbagai Unit Organisasi/perangkat daerah.

Puskesmas merupakan salah satu institusi pelayanan publik yang diselenggarakan pemerintah dalam hal ini pemerintah daerah mempunyai misi memperlancar akses dan kesempatan untuk memperoleh pelayanan yang mudah dan murah serta menjangkau semua lapisan masyarakat. Demikian pula dengan Puskesmas di wilayah Kabupaten Mojokerto sebagai bagian dari instutusi pelayanan publik yang diselenggarakan pemerintah kabupaten Mojokerto memiliki kewajiban memberikan pelayanan publik yang baik dalam bidang kesehatan, sudah barang tentu harus meningkatkan kualitas 
pelayanannya (Perda Kabupaten Mojokerto No. 11 tahun 2008).

Dalam hal tersebut pengukuran kepuasan masyarakat menjadi elemen penting dalam proses evaluasi kinerja pelayanan dimana tujuan akhir yang hendak dicapai adalah pelayanan yang lebih baik, lebih efisien, dan lebih efektif berbasis dari kebutuhan masyarakat. Pihak stake holder sperlu mengetahui sejauh mana pelayanan publik mampu memenuhi harapan masyarakat disuatu unit pelayanan.Untuk itu dalam rangka mengetahui sejuh mana pelayanan puskesmas di wilayah Kabupaten Mojokerto mampu memenuhi harapan masyarakat maka perlu melaksanakan penelitian Analisis Kepuasan Masyarakat Terhadap Pelayanan 27 Puskesmas di Kabupaten Mojokerto Berdasarkan Indeks Kepuasan Masyarakat.

\section{KERANGKA TEORITIS}

\section{Pengertian Kepuasan Masyarakat}

Kepuasan masyarakat merupakan faktor yang sangat penting dan menentukan keberhasilan suatu badan usaha, karena masyarakat adalah konsumen dari produk yang dihasilkannya. Hal ini didukung oleh pernyataan Hoffman dan Beteson (1997, p.270), yaitu: "weithout custumers, the service firm has no reason to exist". Definisi kepuasan masyarakat menurut Mowen (1995, p.511): "Costumers satisfaction is defined as the overall attitudes regarding goods or services after its acquisition and uses". Oleh karena itu, Institusi pelayanan publik harus dapat memenuhi kebutuhan dan keinginan masyarakat sehingga masyarakat sebagai pengguna menjadi puas.

\section{Atribut kepuasan masyarakat}

Untuk mengukur kepuasan masyarakat digunakan atribut yang berisi tentang bagaimana masyarakat menilai suatu produk atau layanan yang ditinjau dari sudut pandang pelanggan. Menurut Dulka (1994, p.41), kepuasan masyarakat dapat diukur melalui atribut-atribut pembentuk kepuasan yang terdiri atas:

1) Value to price relationship. Hubungan antara harga yang ditetapkan oleh privider untuk dibayar dengan nilai/manfaat yang diperoleh masyarakat.

2) Product value adalah penilaian dari kualitas produk atau layanan yang dihasilkan suatu badan usaha.

3) Product benefit adalah manfaat yang diperoleh masyarakat dari mengkosumsi produk yang dihasilkan oleh badan usaha.

4) Product feature adalah ciri-ciri atau karakteristik tertentu yang mendukung fungsi dasar dari suatu produk sehingga berbeda dengan produk yang ditawarkan pesaing.

5) Product design adalah proses untuk merancang tampilan dan fungsi produk.

6) Product reliability and consistency adalah kekakuratan dan keandalan produk yang dihasilkan oleh suatu badan usaha. 
7) Range of product ar services adalah macam dari produk atau layanan yang ditawarkan oleh suatu istitusi provider.

Berdasarkan Surat Keputusan MENPAN No.14/2017sebagai unsur minimal yang harus ada untuk dasar pengukuran Indeks Kepuasan Masyarakat sebagai berikut :

1) Persyaratan,

2) Sistem, Mekanisme, dan Prosedur,

3) Waktu Penyelesaian

4) Biaya/Tarif

5) Produk Spesifikasi Jenis Pelayanan

6) Kompetensi Pelaksana

7) Perilaku Pelaksana

8) Penanganan Pengaduan, Saran dan Masukan

9) Sarana dan prasarana

\section{Pengertian Pelayanan Publik}

Pelayanan publik dapat diartikan sebagai pemberian layanan (melayani) keperluan orang atau masyarakat yang mempunyai kepentingan pada organisasi itu sesuai dengan aturan pokok dan tata cara yang telah ditetapkan.Pelayanan publik (public services) yang diselenggarakan institusi pemerintah adalah merupakan salah satu perwujudan dari fungsi aparatur negara sebagai abdi masyarakat di samping sebagai abdi negara. Pelayanan publik (public services) tersebut dimaksudkan untuk mensejahterakan masyarakat (warga negara) dari suatu negara kesejahteraan (welfare state).Dengan demikian pelayanan publik dapat diartikan sebagai pemberian layanan (melayani) keperluan orang atau masyarakat yang mempunyai kepentingan pada organisasi itu sesuai dengan aturan pokok dan tata cara yang telah ditetapkan.

Pelayanan publik yang profesional, artinya pelayanan publik yang dicirikan oleh adanya akuntabilitas dan responsibilitas dari pemberi layanan (aparatur pemerintah), dengan kriteria sebagai berikut :

1) Efektif, lebih mengutamakan pada pencapaian apa yang menjadi tujuan dan sasaran;

2) Sederhana, mengandung arti prosedur/tata cara pelayanan diselenggarakan secara mudah, cepat, tepat, tidak berbelit-belit, mudah dipahami dan mudah dilaksanakan oleh masyarakat yang meminta pelayanan;

3) Kejelasan dan kepastian (transparan), mengandung akan arti adanya kejelasan dan kepastian mengenai :

a) Prosedur/tata cara pelayanan;

b) Persyaratan pelayanan, baik persyaratan teknis maupun persyaratan administratif;

c) Unit kerja dan atau pejabat yang berwenang dan bertanggung jawab dalam memberikan pelayanan; 
d) Rincian biaya/tarif pelayanan dan tata cara pembayarannya;

e) Jadwal waktu penyelesaian pelayanan.

4) Keterbukaan, mengandung arti prosedur/tata cara persyaratan, satuan kerja/pejabat penanggungjawab pemberi pelayanan, waktu penyelesaian, rincian waktu/tarif serta hal-hal lain yang berkaitan dengan proses pelayanan wajib diinformasikan secara terbuka agar mudah diketahui dan dipahami oleh masyarakat, baik diminta maupun tidak diminta;

5) Efisiensi, mengandung arti :

a) Persyaratan pelayanan hanya dibatasi pada hal-hal berkaitan langsung dengan pencapaian sasaran pelayanan dengan tetap ememperhatikan keterpaduan antara persyaratan dengan produk pelayanan yang berkaitan;

b) Dicegah adanya pengulangan pemenuhan persyaratan, dalam hal proses pelayanan masyarakat yang bersangkutan mempersyaratkan adanya kelengkapan persyaratan dari satuan kerja/instansi pemerintah lain yang terkait.

6) Ketepatan waktu, kriteria ini mengandung arti pelaksanaan pelayanan masyarakat dapat diselesaikan dalam kurun waktu yang telah ditentukan;

7) Responsif, lebih mengarah pada daya tanggap dan cepat menanggapi apa yang menjadi masalah, kebutuhan dan aspirasi masyarakat yang dilayani;

8) Adaptif, cepat menyesuaikan terhadap apa yang menjadi tuntutan, keinginan dan aspirasi masyarakat yang dilayani yang senantiasa mengalami tumbuh kembang.

Berdasarkan Kep. MENPAN No.14/2017, pelayanan publik adalah segala kegiatan pelayanan yang dilaksanakan oleh penyelenggara pelayanan publik sebagai upaya pemenuhan kebutuhan penerima layanan, maupun dalam rangka pelaksanaan ketentuan peraturan perundang-undangan. Sedangkan asas pelayanan publik sebagai berikut.

a) Transparansi

b) Akuntabilitas

c) Kondisional

d) Partisipasif

e) Kesamaan hak dan Kewajiban /tidak diskriminatif

f) Keseimbangan hak dan kewajiban

\section{Kualitas Pelayanan Publik}

Kualitas merupakan suatu kondisi dinamis yang berhubungan dengan produk, jasa, manusia, proses dan lingkungan yang memenuhi atau melebihi harapan. Kata kualitas sendiri mengandung banyak pengertian, beberapa contoh pengertian kualitas menurut Fandy Tjiptono (1995) adalah :

1) Kesesuaian dengan persyaratan;

2) Kecocokan untuk pemakaian;

3) Perbaikan berkelanjutan; 
4) Bebas dari kerusakan/cacat;

5) Pemenuhan kebutuhan pelangggan sejak awal dan setiap saat;

6) Melakukan segala sesuatu secara benar;

7) Sesuatu yang bisa membahagiakan pelanggan.

Pada prinsipnya pengertian-pengertian tersebut diatas dapat diterima. Yang menjadi pertanyaan adalah ciri-ciri atau atribut-atribut apakah yang ikut menentukan kualitas pelayanan publik tersebut.Untuk dapat mengukur sejauh mana kualitas pelayanan publik yang diberikan oleh institusi pemerintah, perlu ada kriteria yang menunjukkan apakah suatu pelayanan publik yang diberikan dapat dikatakan baik atau buruk.

\section{Pengukuran pelayanan publik}

Organisasi pelayanan publik mempunyai ciri public accuntability, dimana setiap warga negara mempunyai hak untuk mengevaluasi kualitaspelayanan yang mereka terima.Adalah sangat sulit untuk menilai kualitas suatu pelayanan tanpa mempertimbangkan peran masyarakat sebagai penerima pelayanan dan aparat pelaksana pelayanan itu.Evaluasi yang berasal dari pengguna pelayanan merupakan elemen penting dalam mengukur kualitas pelayanan publik.

\section{Indeks Kepuasana Masyarakat (IKM)}

Indeks Kepuasan Masyarakat adalah data dan informasi tentang tingkat kepuasan masyarakat yang diperoleh dari hasil pengukuran secara statistik dan pemaparan atas apenadapat myarakat dalam memperoleh pelayanan dari aparatur penyelenggara pelayanan publik dengan mebandingkan antar harpan dan kebutuhan nya(Kep. MENPAN No 14/2017). Manfaat IKM adalah Sebagai Berikut:

1) Diketahui kelemahan atau kekurangan dari masing masing unsur dalam penyelenggaraan pelayanan pubilik

2) Diketahui kinerja penyelenggara pelayanan yang telah dilaksanakan oleh unit pelayanan publiksecara berkala.

3) Sebagai bahan penetapan kebijakan yang perlu diambil dan upaya yang perlu dilakukan

4) Diketahui indeks kepuasan mayarakat secara menyeluruh terhadap hasil pelaksanaan pelayanan publik pada lingkup pemerintahan pusat dan daerah

5) Memacu persaingan positif, antar unit penyelenggara pelayanan publik lingkup pemerintah pusat dan daerah dalm upaya peningkatan kinerja pelayanan

6) Bagi Masyarakat dapat diketahui gambaran tentang knerja unit pelayanan.

Hal yang baru dalam keputusan ini antara lain mencantumkan kuesioner untuk melakukan survey, juga mencakup langkah-langkah penyusunan Indeks Kepuasan Masyarakat (IKM). Pengukuran IKM di unit pelayanan publik yang merupakan penilaiaan mengenai kinerja pegawai sebagai sumber daya manusia penyelenggara pelayanan kepada mayarakat. 


\section{METODE PENELITIAN}

\section{Perspektif Pendekatan Penelitian}

Penelitian ini menggunakan rancangan atau desain penelitian deskriptif kualitatif yaitu mixed antara kualitatif dengan kuantitatif untuk mengetahui Indeks Kepuasan Masyarakat dari pelayanan institusi fasilitas kesehatan tingkat pertama (Puskesmas) di wilayahpemerintah Kabupaten Mojokerto

\section{Lokasi dan Obyek Penelitian.}

Obyek penelitian ini adalah 27 Puskesmas di wilayah kabupaten Mojokerto, Jawa Timur

\section{Jenis dan Sumber Data}

1) Jenis Data

Data yang digunakan dalam penelitian ini berupa data primer dan data sekunder, yang berbentuk kuantitatif dan kualitatif. Data kuantitatif berupa angka-angka, skala-skala, tabel-tabel yang diolah menggunakan formulasi matematis.

2) Sumber Data

Sumber data yang mendukung jawaban permasalahan dalam penelitian dengan cara sebagai berikut:

a) Sumber Data Primer.

Responden dalam pengambilan data primer yaitu masyarakat yang menerima pelayanan langsung dari 27 Puskesmas di kabupaten Mojokerto. Pengumpulan data dari responden dilakukan dengan teknik wawancara dan kuisioner.

b) Sumber Data Sekunder.

Data yang diperoleh dari artikel, buku, makalah, monografi, arsip, catatan dokumen, data statistik dan naskah-naskah yang telah tersedia dalam lembaga atau instansi yang berhubungan dengan penelitian ini.

\section{Instrumen Penelitian}

Instrumen penelitian yang akan digunakan adalah kuesioner. Kuesioner penelitian kemudian dibagikan kepada 150 responden tiap puskesmas dibuat dalam bentuk rating scale sesuai dengan skala pengukuran yang dipakai.Jumlah responden ini adalah sesuai dengan jumlah responden yang dipersyaratkan dalam kepmen PAN No. 14 tahun 2017.

\section{Populasi dan Teknik Pengambilan Sampel}

Populasi dalam penelitian ini adalah seluruh masyarakat Kabupaten Mojokerto dan berhak menerima pelayanan kesehatan di Puskesmas Kabupaten Mojokerto. Sedangkan teknik pengambilan sampel secara accidental sampling, yaitu masyarakat yang datang ke puskesmas untuk menerima pelayanan puskesmas Kabupatan Mojokerto. 


\section{Kuswadi Rustam}

\section{Teknik Analisis Data.}

Teknik analisis datanya menggunakan nilai Indeks Kepuasan Masyarakat (IKM) yang dihitung dengan menggunakan nilai rata-rata tertimbang masing-masing unsur pelayanan. Penghitungan IKM menggunakan 9 indikator unsur kepuasan masyarakat sesuai ketentuan yang berlaku. Setiap unsur pelayanan mempunyai penimbang yang sama dengan rumus sebagai berikut :

Bobot nilai rata - rata tertimbang $=\frac{\text { Jumlah bobot }}{\text { Jumlah Unsur }}=\frac{1}{9}=0,11$

nilai IKM didapatkan dari hasil formulasi berikut:

$I K M=\frac{\text { Total nilai presepsi masing - masing unsur }}{\text { Total unsur yang terisi }} x$ Nilai Penimbang

Kisaran nilai interpretasi nilai IKM adalah 25-100, sehingga hasil penilaian masing-masing nilai IKM pada unit pelayanan dikalikan 25 .

\section{Nilai IKM Unit Pelayanan $\times 25$}

Hasil perhitungan tersebut selanjutnya dikonversi menjadi penilaian deskriptif yang disajikan pada tabel berikut:

Tabel 1.1

Nilai Persepsi, Interval IKM, Interval Konversi IKM

\begin{tabular}{|c|c|c|c|c|}
\hline $\begin{array}{c}\text { Nilai } \\
\text { Presepsi }\end{array}$ & $\begin{array}{c}\text { Nilai Interval } \\
\text { (NI) }\end{array}$ & $\begin{array}{c}\text { Nilai Interval } \\
\text { Konversi (NIK) }\end{array}$ & $\begin{array}{c}\text { Mutu } \\
\text { Pelayanan (x) }\end{array}$ & $\begin{array}{c}\text { Kinerja Unit } \\
\text { Pelayanan (y) }\end{array}$ \\
\hline 1 & $1,00-2,5996$ & $25,00-64,99$ & D & Tidak baik \\
\hline 2 & $2,60-3,064$ & $65,00-76,60$ & C & Kurang baik \\
\hline 3 & $3,0644-3,532$ & $76,61-88,30$ & B & Baik \\
\hline 4 & $3,5324-4,00$ & $88,31-100.00$ & A & Sangat baik \\
\hline
\end{tabular}

\section{HASIL PENELITIAN DAN PEMBAHASAN}

Indeks Kepuasan Masyarakat (IKM) yang dihasilkan dari proses perhitungan, memiliki kisaran angka indeks antara 25 sampai dengan 100. Semakin tinggi nilai indeks kepuasan masyarakatnya menunjukkan masyarakat semakin puas terhadap 
kualitas suatu layanan.Sebaliknya semakin rendah nilai indeks kepuasan masyarakat menunjukkan masyarakat semakin tidak puas terhadap kualitas suatu layanan.

\section{Indeks Setiap Unsur Pelayanan}

Sesuai dengam prinsip pelayanan sebagaimana telah ditetapkan dalam Peraturan Menteri Pendayaagunaan Aparatur Negara Nomor 14 tahun 2017, yang kemudian dikembangkan menjadi 9 unsur yang "relevan", "valid" dan "reliabel", sebagai unsur minimal yang harus ada untuk dasar pengukuran survey kepuasan masyarakat. Adapun Hasil nilai rata-rata unsur dan masing-masing unit pelayanan adalah sebagaimana tabel berikut:

\section{1) Indeks Unsur Persyaratan Pelayanan (U1)}

Nilai konversi rata-rata puskesmas pada unsur persyaratan pelayanan adalah 86,72 . Mengingat nilai konversi tersebut berada pada nilai interval konversi 76,61 - 88,30, maka nilai rata-rata mutu pelayananpuskesmas pada unsur persyaratan pelayananadalah B. Dengan demikian rata-rata kinerja pelayanan puskesmas pada unsur persyaratan pelayanan (U1) adalah Baik

\section{Grafik 1.1}

Nilai Konversi dan Rerata Nilai Konversi Setiap Puskesmas Berdasarkan Unsur Persyaratan Pelayanan

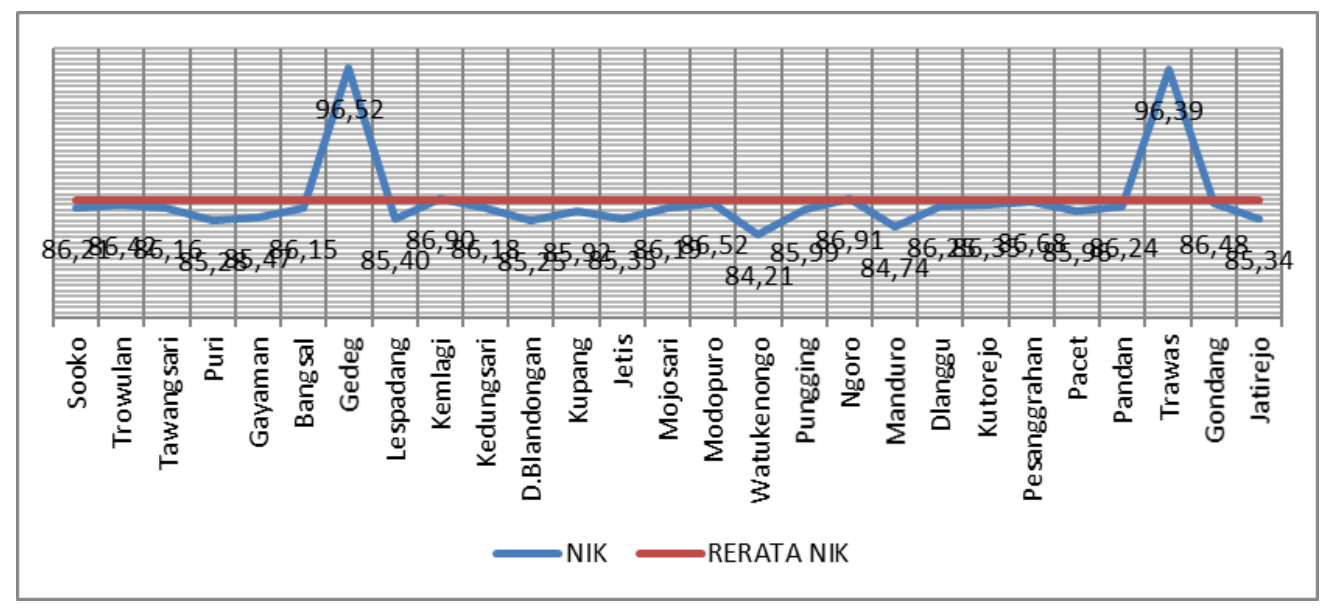

Sumber : Survey tahun 2018

Berdasarkan grafik 1.1. Puskesmas Gedeg dan Puskesmas Trawas memperoleh nilai konversi tertinggi masing-masing 96,52 dan 96,39 berada pada nilai interval konversi 88,31 - 100,00 sehingga mutu pelayanan keduanya padaunsur persyaratan adalah A. Dengan demikian kinerja pelayanan keduanya pada unsur persyaratan pelayanan (U1) adalah Sangat Baik. Sementara itu nilai konversi unsur persyaratan 
pelayanan terendah adalah Puskesmas Watukenongo 84,21, namun demikian masih berada pada nilai interval konvesi dengan katagori kinerja pelayanan pada unsur persyaratan pelayanan (U1) baik. Hanya dua puskesmas yang nilai konversinya berada di atas rata-rata nilai konversi yaitu Puskesmas Gedeg dan Puskesmas Trawas, sementara 25 Puskesmas lainnya berada di bawah rata-rata nilai konversi.

\section{2) Indeks Unsur Prosedur Pelayanan (U2)}

Rata-rata nilai konversi unsur prosedur pelayanan dari 27 puskesmas sebesar 85,98 berada pada nilai interval konversi $76,61-88,30$, sehingga nilai rata-rata mutu pelayananunsur prosedur pelayanan adalah $B$. Dengan demikian rata-rata kinerja pelayanan puskesmas pada unsur prosedur pelayanan (U2) adalah Baik

\section{Grafik 1.2}

Nilai Konversi dan Rerata Nilai Konversi Setiap Puskesmas Berdasarkan Unsur Prosedur Pelayanan

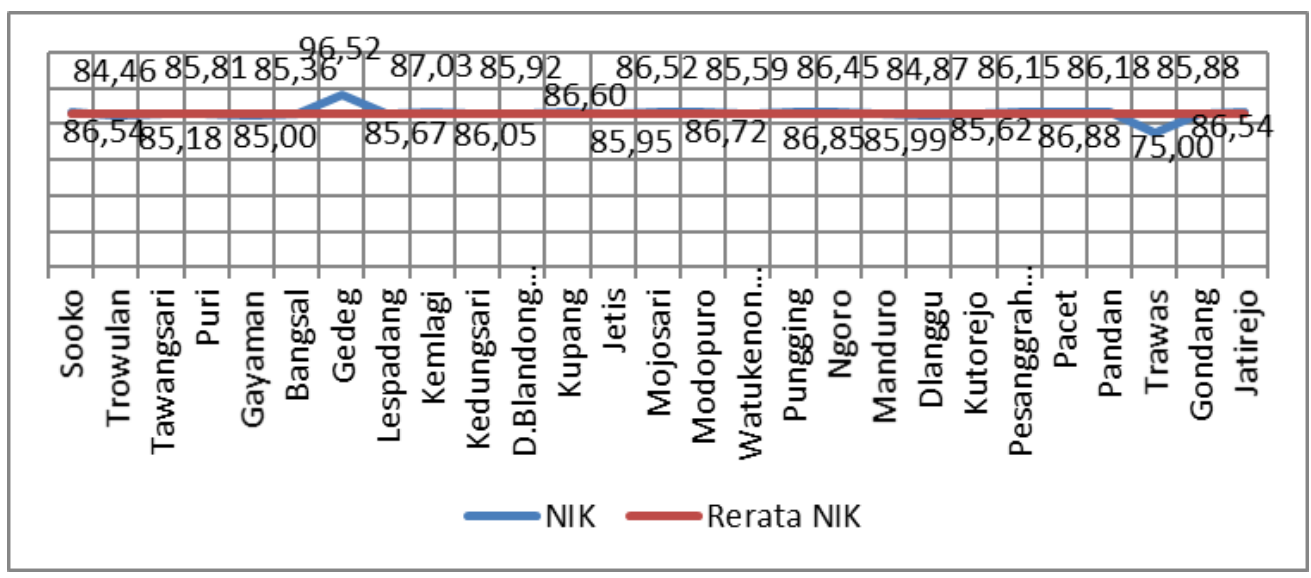

Sumber : Survey tahun 2018

Berdasarkan grafik 1.2.hanya terdapat satu puskesmas yang memiliki nilai konversi tertinggi 96.52 yaitu Puskesmas Gedeg.Jika mengacu pada nilai interval konversi 88,31 - 100,00 maka mutu pelayanan puskesmas tersebut pada unsur prosedur pelayanan adalah A, sehingga kinerja pelayanannnya pada unsur prosedur pelayanan (U2) adalah Sangat Baik.Sementara puskesmas Trawas memperoleh nilai konversi terendah yaitu 75.00. Sesuai nilai interval konvesi pelayanan angka tersebut berada nilai interval konversi $65,00-76,60$, sehingga puskesmas trawas untuk nilai mutu pelayanan adakah C, dengan demikian kinerja pelayanan Puskesmas Trawas pada unsur prosedur pelayanan adalah kurang baik. 


\title{
3) Indeks Unsur Waktu Pelayanan (U3)
}

Rata-rata nilai konversi puskesmas pada unsur waktu pelayanan adalah 86,50 ,berada pada nilai interval konversi $76,61-88,30$, sehingga nilai rata-rata mutu pelayananpuskesmas pada unsur waktu pelayanan adalah B. Dengan kata lain rata-rata kinerja pelayanan puskesmas pada unsur waktu pelayanan. adalah Baik

\author{
Grafik 1.3
}

Nilai Konversi dan Rerata Nilai Konversi Setiap Puskesmas Berdasarkan Waktu Pelayanan

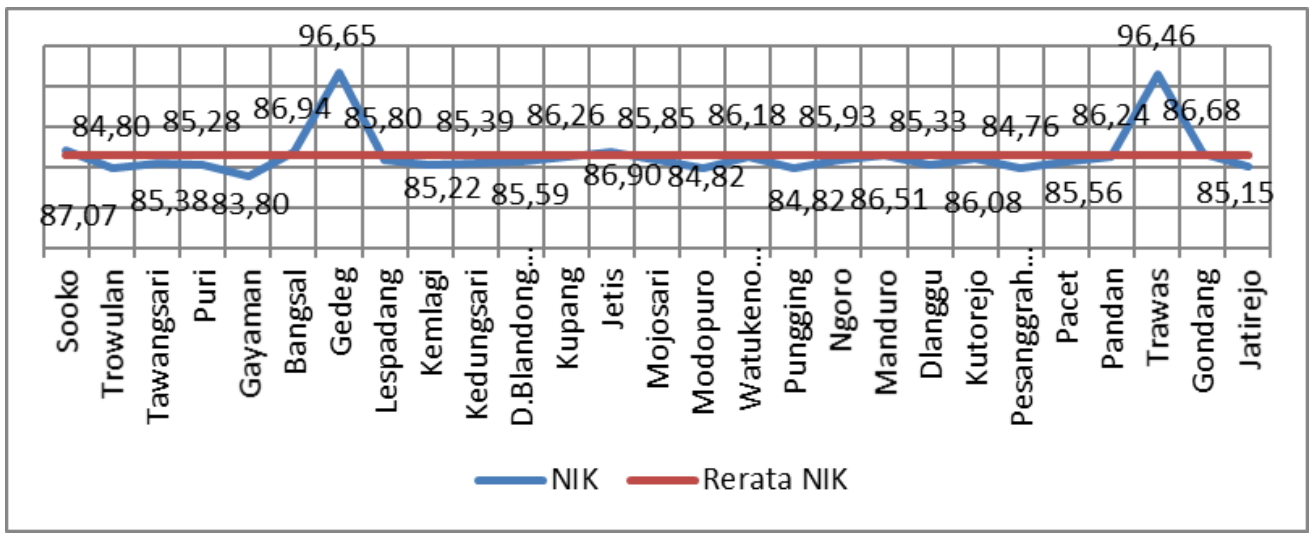

Sumber : data survey 2018

Berdasarkan grafik 1.3.Terdapat dua puskesmas yang memiliki nilai konversi tinggi 96.65 dan 96.46 yaitu Puskesmas Gedeg dan Puskesmas Trawas.Mengacu pada nilai interval konversi 88,31 - 100,00 maka mutu pelayanan keduapuskesmas tersebut pada unsur waktu pelayanandengan kagoriA, sehingga kinerja pelayanann keduanya pada unsur waktu pelayanan (U3) adalah Sangat Baik.Sementara itu puskesmas Gayaman pada unsur waktu pelayanan ini memperoleh nilai konversi terendah yaitu 83.80. Namun sesuai nilai interval konversi masih berada pada katagori nilai mutu pelayanan B, dengan kata laian masih bereda pada kinerja pelayanan puskesmas unsur waktu pelayanan Baik.

\section{4) Indeks Unsur Biaya/Tarif (U4)}

Nilai konversi rata-rata puskesmas unsur Biaya/tarif adalah 89,01 , berada pada nilai interval konversi $88,31-100,00$, maka nilai rata-rata mutu pelayanan puskesmas pada unsur biaya/tarif adalah A. Dengan demikian rata-rata kinerja pelayanan puskesmas pada unsur biaya/tarif (U4) adalah SangatBaik 


\section{Grafik 1.4}

Nilai Konversi dan Rerata Nilai Konversi

Setiap Puskesmas Berdasarkan Unsur Biaya/Tarif

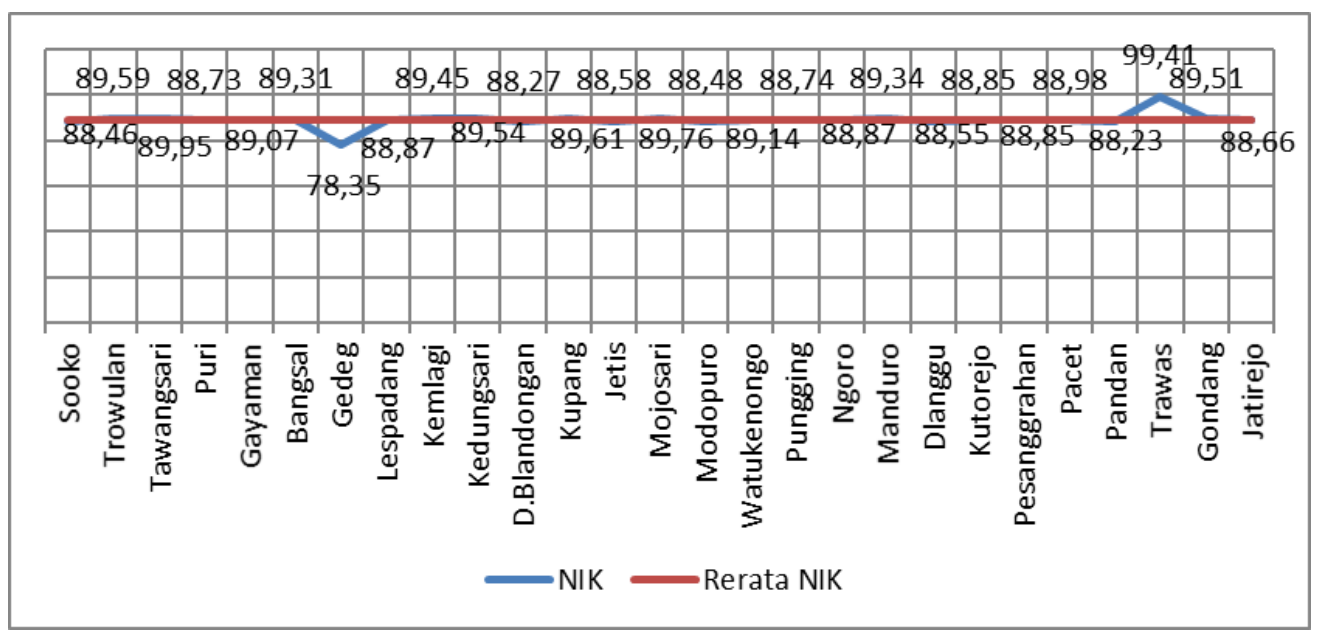

Sumber : Survey tahun 2018

Berdasarkan grafik 1.4 Puskesmas Trawas memperoleh nilai konversi tertinggi99,41 hal tersebut berada pada nilai interval konversi 88,31 - 100,00 sehingga nilai mutu pelayanan puskesmas Trawas padaunsur biaya/tarif adalah A. Dengan lain kata puskesmas Trawas masuk dalam katagorikinerja pelayanannya pada unsur biaya/ tarif (U4) Sangat Baik.Adapun nilai konversi terendah terendah adalah Puskesmas Gedeg mencapai 78,5, namun demikian masih berada pada nilai interval konvesi katagori kinerja pelayanan puskesmasunsur biaya /tarifBaik.

\section{5) Indeks Unsur Produk Spesifikasi (U5)}

Rata-rata nilai indeks konversi puskesmas pada unsur produk spesifikasi adalah 86,39 , berada pada nilai interval konversi $76,61-88,30$, sehingga nilai rata-rata mutu pelayanan puskesmas pada produk spesifikasi adalah B. Dengan kata lain rata-rata kinerja pelayanan puskesmas pada unsur produk spesifikasiini adalah Baik 
Grafik 1.5

Nilai Konversi dan Rerata Nilai Konversi Setiap Puskesmas Berdasarkan Unsur Produk Spesifikasi

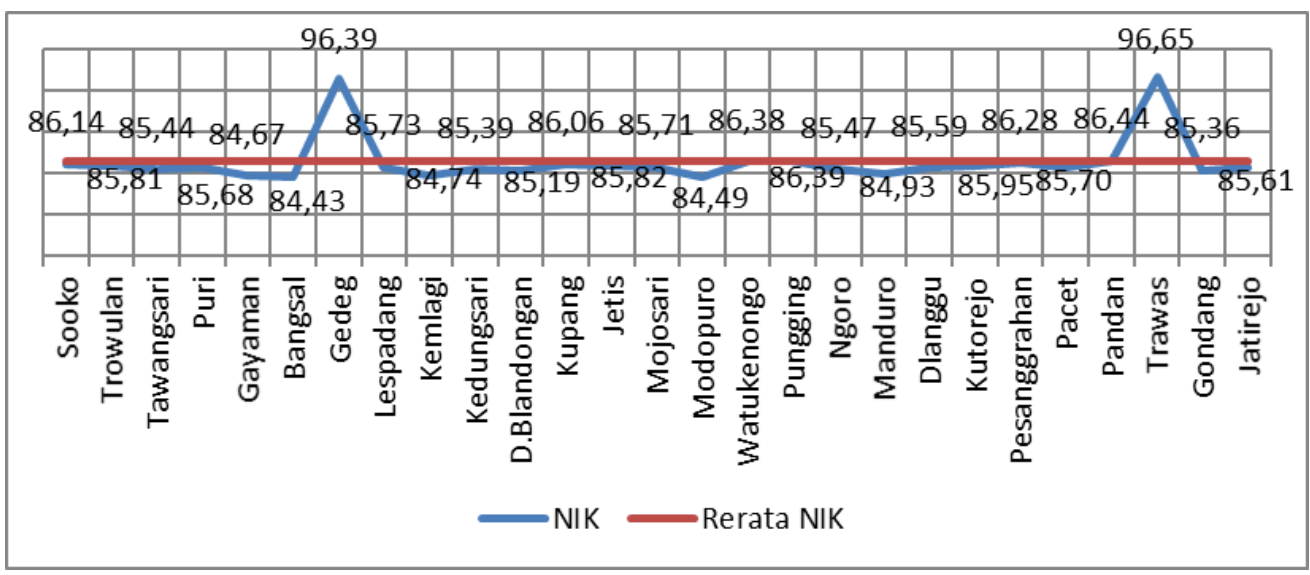

Sumber : data survey 2018

Berdasarkan grafik 1.5. Terdapat dua puskesmas yang memiliki nilai konversi tinggi 96.65 dan 96.39 yaitu Puskesmas Trawas dan Puskesmas Gedeg. Mengacu pada nilai interval konversi 88,31 - 100,00 maka nilai mutu pelayanan kedua puskesmas tersebut pada unsur produk spesifikasiadalahA,Dengan demikian kinerja pelayanann keduanya pada unsur produk spesifikasi (U5) adalah Sangat Baik. Sementara itu puskesmas Bangsal pada unsur produk spesifikasi ini memperoleh nilai konversi terendah yaitu 84.43 . Namun sesuai nilai interval konversi masih berada pada katagori nilai mutu pelayanan $B$, dengan kata lain masih bereda pada kinerja pelayanan puskesmas unsur produk spesifikasiBaik.

\section{6) Indeks Unsur Kompetensi Pelaksana (U6)}

Rata-rata nilai indeks konversi puskesmas pada unsur Kompetensi Pelaksana adalah 85,91, berada pada nilai interval konversi 76,61 - 88,30, sehingga nilai rata-rata mutu pelayanan puskesmas pada Kompetensi Pelaksana adalah B. Dengan kata lain rata-rata kinerja pelayanan puskesmas pada unsur Kompetensi Pelaksana ini adalah Baik 
Grafik 1.6

Nilai Konversi dan Rerata Nilai Konversi

Setiap Puskesmas Berdasarkan Unsur Kompetensi Pelaksana

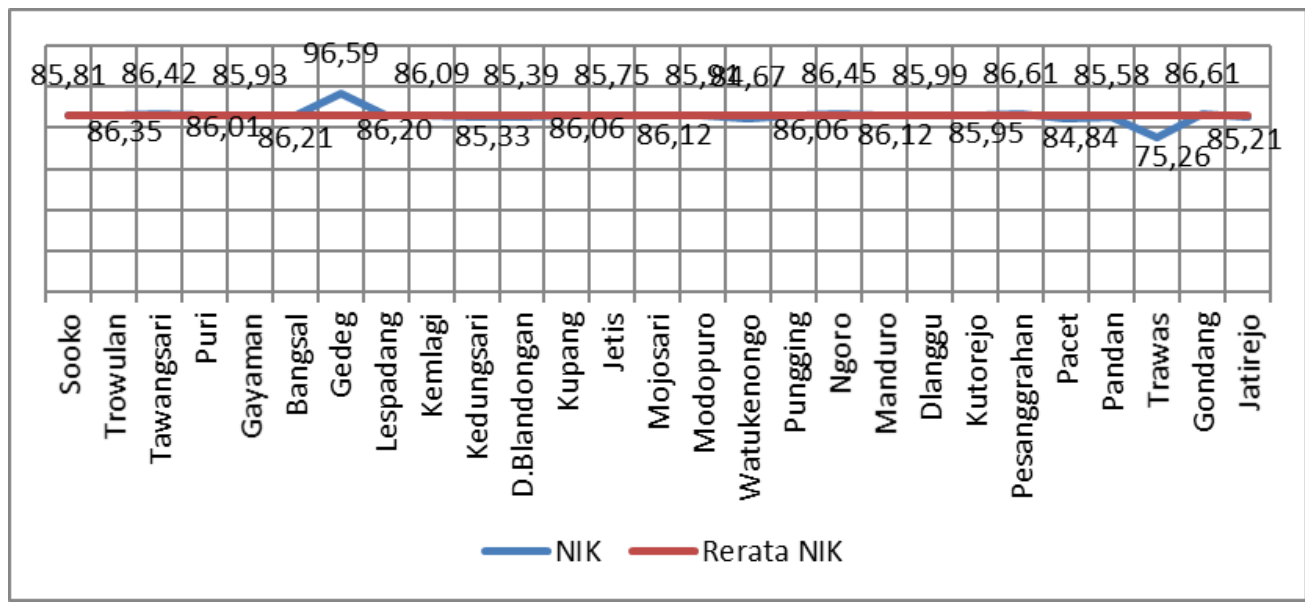

Sumber : data survey 2018

Berdasarkan grafik 1.6.Puskesmas yang memiliki nilai konversi tinggi 96,59yaitu Puskesmas Gedeg. Mengacu pada nilai interval konversi 88,31 - 100,00 maka nilai mutu pelayanan kedua puskesmas tersebut pada unsur Kompetensi PelaksanaadalahA, sehingga kinerja pelayanan puskesmas tersebut pada unsur Kompetensi Pelaksana (U6) adalah Sangat Baik. Sementara itu puskesmas Trawas pada unsur Kompetensi Pelaksana ini memperoleh nilai konversi terendah yaitu 75.26. Sesuai nilai interval konversi Puskesmas Trawas pada katagori nilai mutu pelayanan $\mathrm{C}$, dengan kata lain Puskesmas Trawas kinerja pelayanan pada unsur Kompetensi Pelaksanaadalah Kurang Baik.

\section{7) Indeks Unsur Perilaku Pelaksana (U7)}

Rata-rata nilai indeks konversi puskesmas pada unsur Perilaku Pelaksana adalah 85,81 , berada pada nilai interval konversi 76,61 - 88,30, sehingga nilairata-rata mutu pelayanan puskesmas pada Perilaku Pelaksana adalah B. Dengan kata lain rata-rata kinerja pelayanan puskesmas pada unsur Perilaku Pelaksanaadalah Baik 


\section{Grafik 1.7}

Nilai Konversi dan Rerata Nilai Konversi Setiap Puskesmas Berdasarkan Unsur Perilaku Pelaksana

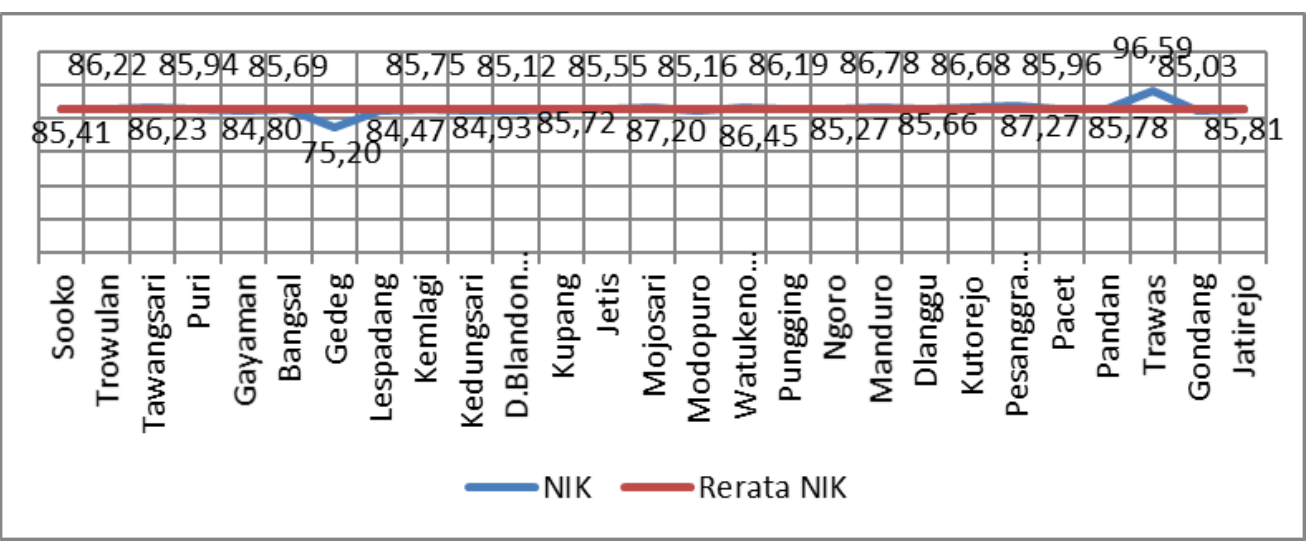

Sumber : data survey 2018

Berdasarkan grafik 1.7.Puskesmas yang memiliki nilai konversi tinggi 96,59yaitu Puskesmas Trawas. Sesuai nilai interval konversi 88,31 - 100,00 maka nilai mutu pelayanan puskesmas Trawas pada unsur Perilaku Pelaksana dengan adalahA,dengan demikiankinerja pelayanan puskesmas tersebut pada unsur Perilaku Pelaksana (U7) adalah Sangat Baik. Sementara itu puskesmas Gedeg pada unsur Perilaku Pelaksana ini memperoleh nilai konversi terendah yaitu 75.20. Sesuai nilai interval konversi 65.00 -76.60, Puskesmas Gedegberada pada nilai mutu pelayanan C, dengan kata lain Puskesmas Gudeg kinerja pelayanan pada unsur Kompetensi Pelaksanaadalah Kurang Baik.

\section{8) Indeks Unsur Penanganan Pengaduan (U8)}

Rata-rata nilai indeks konversi puskesmas pada unsur Penanganan Pengaduan adalah 84,80 , berada pada nilai interval konversi $76,61-88,30$, sehingga nilairata-rata mutu pelayanan puskesmas pada Penanganan Pengaduan adalah B. Dengan kata lain rata-rata kinerja pelayanan puskesmas pada unsur Penanganan Pengaduanadalah Baik 


\section{Grafik 1.8}

Nilai Konversi dan Rerata Nilai Konversi

Setiap Puskesmas Berdasarkan Unsur Penanganan Pengaduan

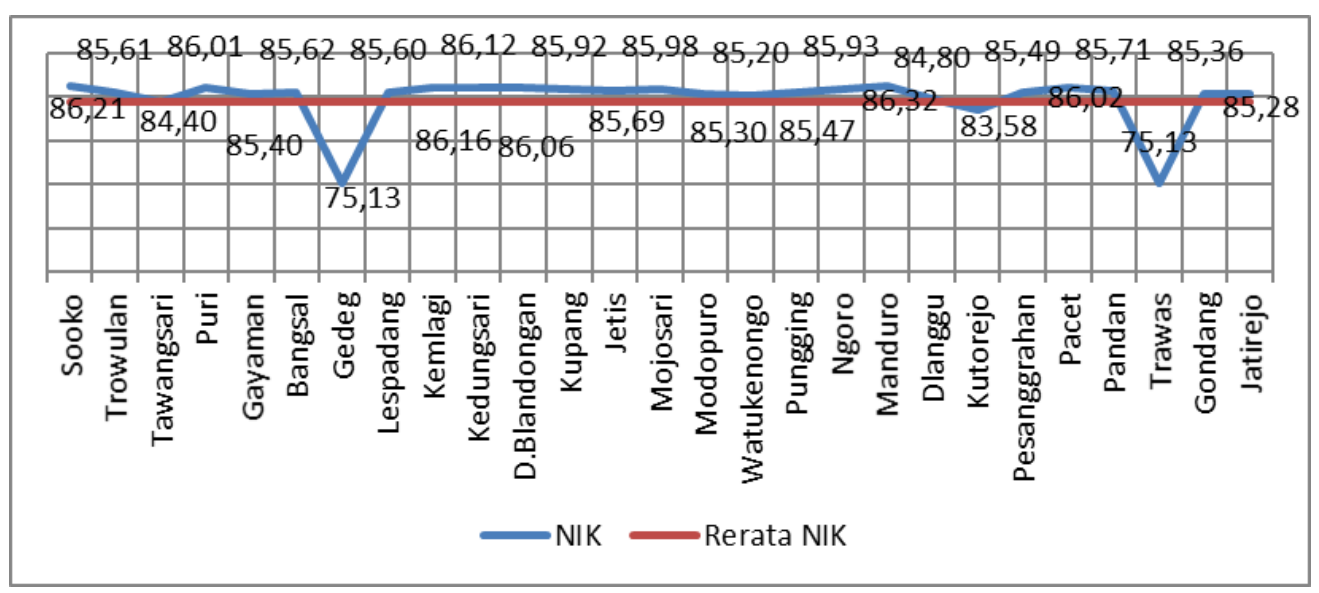

Sumber : data survey 2018

Berdasarkan grafik 1.8. Terdapat 3 Puskesmas yang memiliki nilai konversi dibawah rata-rata yaitu Puskesmas Gedeg 75.13, Puskesmas Trawas 75, 13 dan Puskesmas Kutorejo 83,58. Khusus Puskesmas Gedeg dan Puskesmas Trawas sesuai sesuai nilai interval konversi 65.00 -76.60,kedua puskesmas tersebut nilai mutu pelayanan yang diperoleh adalah $\mathrm{C}$, dengan kata lain kinerja pelayanan pada unsur penanganan pengaduanadalah Kurang BaikSementara 24 puskesmas lainnya berada diatas rata-rata dan sesuai nilai interval konversi 76,61 - 88,30 sehingganilai mutu pelayanan ke 24 puskesmas pada unsur penanganan pengaduan dengan katagori $\mathrm{B}$,Dengan demikian kinerja pelayanan puskesmas tersebut pada unsur penanganan pengaduan (U8) adalah Baik.

\section{9) Indeks Unsur Sarana dan Prasarana (U9)}

Rata-rata nilai indeks konversi puskesmas pada unsur sarana dan prasarana adalah 86,59 Berdasarkan nilai interval konversi 76,61 - 88,30 nilai tersebut berada pada nilai rata-rata mutu pelayanan puskesmas pada sarana dan prasaranaadalah B. Dengan kata lain rata-rata kinerja pelayanan puskesmas pada unsur sarana dan prasaranaadalah Baik 


\section{Grafik 1.9}

Nilai Konversi dan Rerata Nilai Konversi

Setiap Puskesmas Berdasarkan Unsur Sarana dan Prasarana

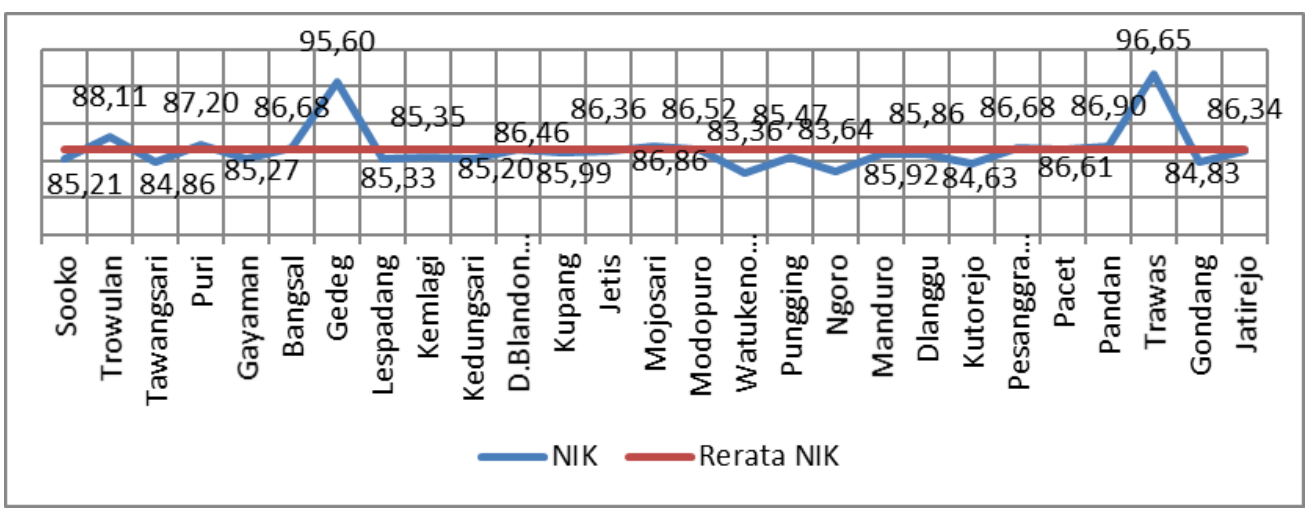

Sumber : data survey 2018

Berdasarkan grafik 1.9.Puskesmas yang memiliki nilai konversi tinggi yaitu Puskesmas Trawas 96,65 dan Puskesmas Gedeg 95,60. Sesuai nilai interval konversi 88,31 - 100,00 maka nilai mutu pelayanan kedua puskesmas tersebut pada unsur sarana dan prasaranaadalahA,sehingga kinerja pelayanan puskesmas tersebut pada unsur sarana dan prasarana (U9) adalah Sangat Baik. Sementara itu puskesmas Watukenongo pada unsur sarana dan prasarana ini memperoleh nilai konversi terendah yaitu 83,36. Namun demikian sesuai nilai interval konversi 76.61 -88.30, Puskesmas tersebutmasihberada pada nilai mutu pelayanan B, dengan kata lain Puskesmas Watukenongo memiliki kinerja pelayanan pada unsur sarana dan prasaranaadalah Baik.

\section{0) Indeks Kepuasan Masyarakat Puskesmas}

Rata-rata indeks kepuasan Masyarakatpada 27 Puskesmas mencapai 86,33Jika berdasarkan interval konversi 76,61 - 88,30, makarata-rata IKM Puskesmas di Wilayah Kabupaten Majokerto berada pada nilai mutu pelayanan mencapai nilai mutu pelayanmanB, atau rata-rata capaian IKM puskesmas di kabupaten MajokertoadalahBaik 
Grafik 1.10

IKM Setiap Puskesmas dan Rerata IKM Puskesmas

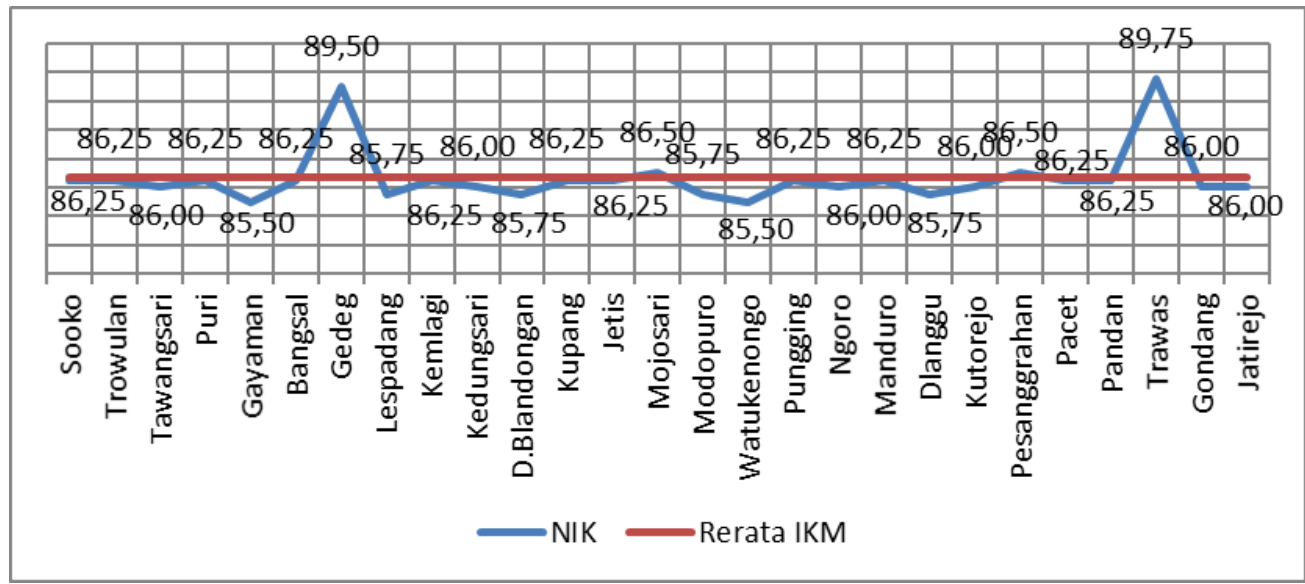

Sumber : data Survey 2018

Berdasarkan grafik 1.10.Terdapat dua puskesmas yang memilikiIKM tertinggi yaitu Puskesmas Trawas 89.75 dan Puskesmas Gedeg 89,50 . Sesuai interval konversi 88,31 - 100,00 maka IKM kedua puskesmas tersebut mencapai mutu pelayananA,dengan kata lain menunjukkan bahwakinerja pelayanankedua puskesmas tersebut Sangat Baik. Sementara ituIKM terendah masingmasing sebesar 85,50 dicapai oleh Puskesmas Gayaman dan Puskesmas Watukenongo.Namun demikian sesuai nilai interval konversi $76.61-88.30$, kedua puskesmas itumasihdalam katagori nilai mutu pelayanan mencapai $\mathrm{B}$, sehingga keduanya memiliki kinerja pelayanan adalahBaik.

\section{KESIMPULAN DAN SARAN}

Berdasarkan hasil penelitian dan pembahasanterdapat kesimpulan sebagai berikut :

1) Rata-rataNilai Konversi Unsur Pelayanan

Nilai rata-rata konversi setiap unsur pelayanan dari 27 puskesmas paling tinggi adalah nilai konversi pada unsur biaya/tarif (U4) adalah 89,01 atau mencapai nilai mutu pelayanan $\mathrm{A}$, dengan demikian rata-rata kinerja pelayanan puskesmas pada unsur biaya/tarif adalah sangat baik. Sementara nilai rata-rata konversi terendah adalah unsur pelayanan Penaganan Pengaduan (U4) 84.40, berada pada nilai mutu pelyananan $\mathrm{B}$, atau dengan kinerja pelayanan pada unsur penanganan pengaduan Baik.

2) Rata-rata IKM Puskesmas

Berdasarkan grafik 1.11.secara keseluruhan terdapat 7 puskesmas atau sebanyak $25,93 \%$ yang memiliki IKM di atas rata-rata IKM 86,33. Dari 7 puskesmas 
tersebut hanya dua puskesmas yang mencapai IKM sangat baik yaitu Puskesmas Trawas 89.75 dan Puskesmas Gedeg 89,50, sedangkan sisanya mencapai IKM Baik. Sementara sisanya $74.07 \%$ atau sebanyak 20 Puskesmas memiliki IKM dibawah rata-rata IKM seluruh puskesmas dan semuanya mencapai IKM Baik.

3) Penelitian Analisis Kepuasan Masyarakat Terhadap Pelayanan Puskesmas ke depan diharapkan lebih menfokuskan pada unit-unit pelayanan masyarakat yang ada di tiap puskesmas karena tiap unit pelayanan dan tiap puskesmas memiliki karakteristik pelayanannya masing-masing.

\section{DAFTAR PUSTAKA}

Barata, Atep Adya, 2003, Dasar-dasar Pelayanan Prima, PT. Elex Media Komputindo, Jakarta.

Bryson, John M., 1995, Strategic Planning for Public and Non Profit Organizations, A Guide to Strengthening and Sustainin Organizational Achievement, Revisied Edition, Josey-Bass Publisher, San-Francisco.

Cascio, Wayne F., 1992, Managing Human Resources : Produktivity, Quality, of Work life, Profits, McGraw-Hill, Inc, New York.

Denhardt, Janet V. and Denhardt, Robert B.2003, The New Public Service : Serving, not Steering, New York, M.E. Sharpe, Inc.

Dwiyanto,Agus, 1995, Penilaian Kerja Organisasi Pelayanan Publik, Makalah disampaikan pada Seminar Kinerja Organisasi Publik, Fisipol UGM, Yogyakarta.

Dwiyanto, Agus, Partini, Ratmito, Wicaksono, Bambang, Tamtiari, Wini, Kusumasari, Beveola, nuh, Muhammad, 2002, Reformasi Birokrasi Publik di Indonesia, diterbitkan Pusat Studi Kependudukan dan Kebijakan UGM, Galang Printika, Yogyakarta.

Dwiyanto, Agus, dkk.2003, Reformasi Tata pemerintahan dan Otonomi Daerah, Pusat studi Kepedudukan dan Kebijakan Universitas Gajah Mada, Yogyakarta.

Gasperz, Vincent, 1997. Manajemen Kualitas Dalam Industri Jasa, PT. Gramedia Pustaka, Jakarta

Gibson, James L., Ivancevich, John M., Donnely JR., James H., 1996, Organisasi, Perilaku, Struktur, Proses, Edisi Kedelapan, Binarupa Aksara, Jakarta.

Handoko, 1988, Kinerja dan Tingkat Emosional, Pratama, Surabaya.

Harta, R., \& Diana, B. A. (2017). Etos Kerja Profesionalisme Dalam Penyelenggaraan Birokrasi Pemerintahan. Jurnal Manajemen Pelayanan Publik, 1(1), 103-108. 


\section{Kuswadi Rustam}

Keban, Yeremias T., 1995, Indikator Kinerja Pemerintah Daerah: Pendekatan Manajemen dan Kebijakan, Makalah disajikan pada seminar sehari Kinerja Organisasi Publik, Fisipol UGM, Yogyakarta

Kepmen PAN No. 25/M.PAN/2/2004 tentang Pedoman Umum Penyusunan Indeks Kepuasan Masyarakat Unit Pelayanan Instansi Pemerintah.

Kepmen PAN No. 63/M.PAN/7/2003 tentang Pedoman Umum Penyusunan Indeks Kepuasan Masyarakat Unit Pelayanan Instansi Pemerintah.

Keputusan Menteri Pendayagunaan Aparatur Negara Nomor 81 Tahun 1993 Tentang Pedoman Tatalaksana Pelayanan Umum

Lane, Jan-Erik, 1995, The Public Sector, Concept, Models and Approaches, Second Edition, Sage Publication, London.

Laterner dan Levine, 1993, Strategic Planing for Public, Terjemahan oleh Budiono, Hastabuana, Jakarta.

Miftah Thoha, 1995, Kepemimpinan Dalam Manajemen Suatu Pendekatan Perilaku, PT. Grafindo Persada, Jakarta.

Milles, Mattew B. \& Huberman, 1992, Analisis Data Kualitatif, Jakarta, Universitas Indonesia Press.

Moleong, Lexi J., 2000, Metode Penelitian Kualitatif, Remaja Rosdakarya, Bandung.

Moenir, 2001, Manajemen Pelayanan Umum di Indonesia,Jakarta : Bumi Aksara

Siti Maryam, N. (2017). Mewujudkan good governance melalui pelayanan publik. JIPSIJurnal Ilmu Politik dan Komunikasi UNIKOM, 6:1. 1-18.

Nazir, Moh. ( 1985 ). Metode Penelitian. Jakarta: Ghalia Indonesia

Parasuraman A, Valarie A Zeithaml \& Leonard L. Berry, 1994," Reassesment of Expectation As A Comparison Standart In Measuring Servive Quality: Implications For Futher Research", Journal Of Marketing, Vol 58, pp 111-124

Rahayu, Amy Y.S. 1996. Fenomena Sektor Publik dan Era Service Quality Servqual), dalam Bisnis dan Birokrasi, Jurnal Ilmu Administrasi dan Organisasi, I : 1 -19

Rahayu, Amy Y.S, Fenomena Sektor Publik dan Era ervice Quality (Servqual), dalam Bisnis dan Birokrasi, Jurnal Ilmu Administrasi dan Organisasi, 1996, I : 1-19.

Ratminto \& Atik SW. 2005. Manajemen Pelayanan : Pengembangan Model Konseptual, Penerapan Citizen's Charter \& SPM. Yogyakarta : Pustaka Pelajar.

Robbins, Stephen P., 1996, Perilaku Organisasi, Jilid I dan II, Edisi Kedelapan, PT. Prenhallindo, Jakarta.

Salusu J., 1996, Pengambilan Keputusan Strategik untuk Organisasi Publik dan Organisasi Non Profit, Gramedia Widiasarana Indonesia, Jakarta. 
Siagian, Sondang P., 1994, Patologi Birokrasi, Bumi Aksara, Jakarta. Singarimbun, Masri, dan Effendi, Sofian, 1995, Metode Penelitian Survey, Edisi

Kedua, LP3ES, Jakarta. Soeprihanto, John, 2001, Penilaian Kinerja dan Pengembangan Karyawan, BPFE, Edisi Pertama, Yogyakarta.

Neng Kamarmi, S. M. (2011). Analisis Pelayanan Publik Terhadap Masyarakat (Kasus Pelayanan Kesehatan Di Kabupaten Agam). Jurnal Manajemen dan Kewirausahaan, 2, 84-110.

Steers, Richard M., 1985, Efektifitas Organisasi Kaidah Tingkah Laku (terjemahan), Erlangga, Jakarta.

Semil, Nurmah, 2005, Analisis Kinerja Pelayanan Instansi Pemerintah Studi Kasus di Kantor BPN Kota Semarang. Tesis.Semarang : MAP Undip.

Supranto, J., 1997, Pengukuran Tingkat Kepuasan Pelanggan untuk Menaikkan Pangsa Pasar, Rineka Cipta, Jakarta.

Suyanto, Bagong, 2000, Kemiskinan dan Kebijakan Pembangunan, Edisi Pertama, Erlangga, Jakarta.

Suyoto, 1997, Postmodernisme dan Masa Depan Peradaban, Aditya Media, Jakarta.

Tangkilisan, Hassel Nogi S, 2003, Manajemen Modern untuk Sektor Publik. Yogyakarta: Balarairung \& Co.

Thoha, Miftah, 1995, Birokrasi Indonesia Dalam Era Globalisasi, Pd. Batang Gadis, Jakarta.

Tjiptono, Fandy, 2002, Manajemen Jasa, Cetkan ketiga, Penerbit Andi, Yogyakarta.

Tjiptono, Fandy., 1997, Prinsip-prinsip Total Quality (TQS)Yogyakarta : Penerbit ANDI OFSET. 